\title{
The face of health in the West and the East: A semio-cultural analysis
}

\author{
Simona Stano ${ }^{1}$
}

\begin{abstract}
Magazines, leaflets, weblogs, and a variety of other media incessantly spread messages advising us on how to achieve or maintain our health or well-being. In such messages, the iconic representation of the face is predominant, and reveals an interesting phenomenon: the "face of health" seems to be unattainable as such, and is generally represented in a differential way, that is to say, by making reference to its opposite - the "face of illness", or at least of malaise. In fact, the face is crucial in the medical domain: since ancient times, face observation has played an essential role in diagnostic practices, both in Western medicine (which resorts to the concept of facies, intended as the distinctive facial expression or appearance associated with a specific medical condition, for the description of pathological states) and Eastern preventive and healing techniques (within which the so-called Mian Xiang, or 'face reading', is fundamental, and connects the medical sphere with other aspects such as personality, talents, and dispositions). Drawing on the semiotic analysis of relevant case studies extending from classical iconography to present-day digital mediascapes, this paper investigates the representation of the face of health (and illness) across time and space, specifically focusing on the analogies and differences between the Western and the Eastern semiosphere. To this purpose, it relies on both literature concerning the representation and understanding of the face and studies on medical sign systems and discourses.
\end{abstract}

Keywords: face; health; collective imaginary; medicine; West vs. East; semiotics.

1 Department of Philosophy and Education Science, University of Turin (UNITO), Torino, Italy; e-mail: simona.stano@unito.it. 
Proprio nomine dicitur facere a facie, qui rei quam facit imponit faciem. Ut fictor cum dicit fingo, figuram imponit, quom dicit formo, formam, sic cum dicit facio, faciem imponit. Varro, De lingua latina VI, 78

\section{Introduction}

"What does your face say about your health?"; "Have you ever wondered if there is a connection between locations on your face and body organs?"; "The secrets your face tells about your health". These are only a few of the several references to the close relation between the face and health that can be found in posts and articles featured on the Internet. Magazines, leaflets and other media advising us on how to achieve or maintain our health or well-being also insist particularly on the face and its visual representation. What is more, since ancient times, face observation has played an essential role in diagnostic practices, both in Western medicine which resorts to the concept of facies, intended as the distinctive facial expression or appearance associated with a specific medical condition, for the description of pathological states - and Eastern preventive and healing techniques, within which the so-called Mian Xiang, or 'face reading', is fundamental, and connects the medical sphere with other aspects such as personality, talents, and dispositions.

Why has the face been elected as the plane of discursivization of health (or illness) par excellence? How does cultural variation influence such a relation and the facial representation of health? What do such representations tell us about the understanding of health itself? Drawing on the semiotic analysis of relevant case studies extending from classical iconography to present-day digital mediascapes, the following paragraphs aim at addressing these issues, investigating the representation of the face of health across time and space, and specifically focusing on the analogies and differences between the Western and the Eastern semiosphere.

\section{Health: In search of a definition}

Before analysing the link between the face and health, it is worthwhile clarifying, at least briefly, what is meant by these terms.

The face is a complex object of analysis, as suggested by the multiplicity and variety of terms used to refer to it (especially in Romance languages) and their etymology: 
The complexity of the face as an observable, decipherable, and describable object has always posed a quantity of questions that, at different times, have found different answers: sometimes explaining the entire macrocosm through the face, sometimes making the face into a whole macrocosm; sometimes considering it simply as a transparent mirror of passions, sometimes rather conceiving it as a treacherous mask produced by the game of social simulation. Traces of the thousand contradictions characterizing the face in the collective imaginary are inscribed, albeit in a disconnected and fragmentary way, in the etymological history of the natural language terms that have been used to designate it: [in Italian] volto, viso, faccia; in Latin vultus, facies; in French chère, face, figure, vis, visage, vout [...]. ${ }^{2}$ (Magli 1995: 10)

A particular aspect, more than others, is relevant to the purposes of this paper:

The face is above all, in a passive sense, visus, [that is to say] the part of us, of our person and not only of our body, that is more exposed to visibility. It is the part of us that remains most entangled in the game of looks, of seeing and being seen, of showing off and hiding. ${ }^{3}$ (Magli 1995: 10)

As such, the face represents first of all a form, which is subjected to countless strategies of signification and reading (Leone 2018: 27). It is a discourse, that is to say, an utterance, an act of enunciation.

Likewise, health is a multifaceted and not at all univocally defined concept. Traditionally, it has been described mainly in differential terms, that is to say, as the absence of what is generally called 'disease': as Paolo Fabbri (1995: 37) remarked, "the Latin word salus is related to salvus, which means the one who is saved from changes, from disturbances coming from outside. It is a question of total integrity, a kind of 'skin' that saves and puts at ease". ${ }^{4}$ In fact, most Latin-

2 "La complessità del volto come oggetto osservabile, decifrabile, descrivibile, da sempre ha posto una quantità di quesiti a cui, in tempi diversi, si è tentato di dare risposta: ora spiegando l'intero macrocosmo attraverso il volto, ora facendo del volto l'intero macrocosmo, ora considerandolo come specchio trasparente delle passioni, ora come maschera infida prodotta dal gioco della simulazione sociale. Tracce delle mille contraddizioni di cui vive il volto all'interno dell'immaginario collettivo sono iscritte, seppure in modo sconnesso e spesso frammentario, nella storia etimologica dei termini che, all'interno della lingua naturale, lo designano: volto, viso, faccia; in latino vultus, facies; in francese chère, face, figure, vis, visage, vout [...]." (Translations from Italian are mine, unless indicated otherwise, S. S.)

3 "Ma il volto è soprattutto, in senso passivo, visus, quanto di noi, della nostra persona e non solo del nostro corpo, è più esposto alla visibilità. É quanto di noi più resta impigliato nel gioco degli sguardi, del vedere e dell'essere visti, del far mostra di sé e del nascondersi."

4 "Il latino salus è legato a salvus che significa colui che si salva dalle modifiche, dalle perturbazioni provenienti dall'esterno. Si tratta di un'integrità totale, una specie di pelle che salva, che mette tranquilli, elimina le sollecitazioni della curiosità." 
based terms used to designate health (such as, for instance, the Italian 'salute') highlight such a character of "integrity, safety and therefore salvation" (Pianigiani 2020). ${ }^{5}$ The Germanic origin of the old English term 'hōlth', from which the word 'health' derived, also relates to 'whole' (Oxford English Dictionary 2020), ${ }^{6}$ further enhancing such a perspective.

In this sense, as noted by Jacques Fontanille (2005), health is conceived of as an evaluative statement antithetical to disease: the former describes a state that fully conforms to the norm, the latter rather establishes a divergence from it. This asymmetry is then reflected on a pragmatic level, since there seems to be only one way of being healthy, as opposed to a multiplicity of ways of being ill; and also on the syntagmatic level, since health does not seem to have a history (it is a temporal segment), while illness is above all a "narrative sequence" (i.e. an aspectualized" path, including an initial phase - i.e. the onset of the disorder, such as a lesion, or the moment of incubation, etc.; a durative phase - i.e. the development of the disease, consisting for instance in the infection; and a terminative phase i.e. healing, or rather deterioration and death). From a narrative point of view, health corresponds in this view to "a dense and unanalysable 'state, while illness is perceived as a multiplicity of paths implying both losses and gains, emerging problems, crises and healings"8 (Fontanille 2005: 35) - see Table 1.

5 “Integrità, Incolumità e quindi Salvezza." The source, Pianigiani, Ottorino 2020. Dizionario etimologico online, available at https://www.etimo.it, was last accessed on 19 February 2021.

6 Oxford English Dictionary, available at https://www.lexico.com, was last accessed on 19 February 2021.

7 As remarked by Greimas and Courtés (1982[1979]: 18), “all temporalized discourse has two kinds of new investments which produce the two meaning effects of temporality and aspectuality. While the effect of temporality is linked to the establishment of a group of temporal categories which [...] project a temporal organizations of topological nature onto the utterance, the effect of aspectuality results from the investments of aspectual categories which convert the functions (or predicated) of narrative utterances into a process". In this sense, health seems to be closer to the traditional narrative logic of programming, whereas illness features a processual development, which combines punctual and durative phases, perfective or imperfective aspects, iterative or singular sequences.

8 "[...] uno "stato" denso e inanalizzabile, mentre la malattia viene percepita come una molteplicità di percorsi che implicano perdite e guadagni, problemi emergenti, crisi e guarigioni." 
Table 1. The opposition between health and illness.

\begin{tabular}{|c|c|}
\hline Health & Illness \\
\hline $\begin{array}{c}\text { Negative concept } \\
\text { (absence of events) }\end{array}$ & $\begin{array}{c}\text { Positive concept } \\
\text { (presence of events) }\end{array}$ \\
\hline Static balance & Dynamic imbalance \\
\hline Conformity & Divergence \\
\hline Temporal segment & Aspectualized path \\
\hline $\begin{array}{c}\text { Unique, dense, and } \\
\text { unanalysable 'state' }\end{array}$ & $\begin{array}{c}\text { Modular and analysable } \\
\text { multiplicity of 'paths' }\end{array}$ \\
\hline
\end{tabular}

However, as the French scholar effectively remarked, such an approach is too simplistic, and fails to explain a recurring aspect of the disease, which is also a mode of its possible indirect presence within a state of health: the malaise. In fact, according to Fontanille, the malaise can appear in all phases of illness and even in its absence. Even if an external look (such as that of a doctor) can later recognize it as a symptom of a specific illness, the malaise as a feeling or sensation is not necessarily related to the sphere of disease. Such a perspective - which recalls the Barthesian conception of the symptom (Barthes 1972), according to which it is not a sign in itself, but becomes such only when it enters the context of clinical discourse $^{9}$ - is of particular relevance, since it highlights that

[h] ealth is not a restful adventure, and it even seems that it can be better described - going against common sense - as a permanent tension, that is to say, a multi-polemic process. The disease, on the other hand, is almost always the result of a release of tensions (the defenses surrender, the body no longer reacts to attacks, the cells no longer die and begin to proliferate, etc.). [...] Of course, thanks to the constantly changing balances that it manages to guarantee, health manifests itself

9 In his essay "Sémiologie et médecine", Roland Barthes (1972) describes symptoms as brute facts emerging from the body - that is to say, purely phenomenal sensations that are not necessarily linked to any act of interpretation, and so do not constitute semiotic entities as such. Nonetheless, he also supports the view that they turn into signs once they are "put into discourse", that is, when they are "modelled" (in terms of Lotman 1977) through language. Such an opposition is partially overcome by Thomas Sebeok, who pushes further the association between signs and symptoms, conceiving the latter as "compulsive, automatic, nonarbitrary sign[s], such that the signifier coupled with the signified in the manner of a natural link" (Sebeok 1976: 46; cf. Sebeok 2001). In Sebeok's view, symptoms can be seen as a marked category (species) of an unmarked one (genus, that is, the sign), thus acquiring a semiotic status per se. For further details, see, in particular, Stano 2020. 
and makes itself perceived [...] as an absence of events, a stable and durable state. ${ }^{10}$ (Fontanille 2005: 37)

It is therefore necessary to distinguish between two different dynamics. On the level of existence, the difference between health and disease is reduced to a series of narrative transformations and variations of the figurative balances that put health and illness in open opposition, identifying them as antithetical terms. On the level of experience, this distinction is counteracted by the appearance of a specific "feeling" (i.e. the malaise), which brings out the aspectual and transformative nature of health alongside that of illness, putting them in a tensive correlation rather than in a firm opposition.

While requiring to reconsider the definitions and characterizations mentioned above, this view also distinguishes two levels of corporeality that interact in the perception and recognition of health and illness as related processes: the 'Me-flesh' (corps-chair), which participates in the transformation of the states of things and is a "composite totality in existence"11 (Fontanille 2005: 40); and the 'Myself-envelope' (corps propre), understood as a "coherent unity in experience"12 (Fontanille 2005: 40), that is, the "body-in-construction, the living vehicle of intentionality and interactions support, and therefore, particularly the support of confrontation with otherness" (Fontanille 2013: 41).

Moreover, in recent decades another concept has increasingly more been used in relation to health, highlighting its "higher threshold" alongside the "lower threshold" that associates it with disease (Marrone 2005; Sbisà 2005): the idea of well-being, whether real or apparent. This finds a confirmation in the current definition of health in different languages, ${ }^{13}$ as well as in universally shared descriptions such as the one provided by the World Health Organization, which clearly mentions the overcoming of the differential view: "Health is a state of complete physical, mental and social well-being and not merely the absence

10 "La salute non è un'avventura di tutto riposo, e sembra addirittura che la si possa descrivere con precisione - andando in ciò contro al senso comune - soltanto come una tensione permanente, un processo multipolemico. La malattia invece è quasi sempre esito di un rilascio delle tensioni (la difesa cede, il corpo non reagisce più agli attacchi, le cellule non muoiono più e si mettono a proliferare ecc.). [...] Naturalmente, grazie agli equilibri in continuo movimento che riesce a garantire, la salute si manifesta e si fa percepire [...] come uniassenza di evento, uno stato stabile e durevole."

11 "Totalità composita nell'esistenza."

12 "Unità coerente nell'esperienza."

13 The Merriam-Webster Online English Dictionary (2020), for instance, defines health as "the condition of being sound in body, mind, or spirit", also openly associating it with the idea of well-being: "a condition in which someone or something is thriving or doing well". The dictionary was last accessed at https://www.merriam-webster.com on 19 February 2021. 
of disease or infirmity" (WHO 2020: 1). ${ }^{14}$ Not only is a positive definition adopted in this case, but the concept of health is enlarged, encompassing both the psychological and the social dimension. This further emphasizes a phenomenological conception of the body as "a totality of lived significations" (MerleauPonty 2012[1945]: 155), that is to say, both an object in the world and a subject experiencing the world, a part of reality and a means of conjunction with it - a real "threshold of sense" (Stano 2019: 149).

In the following paragraphs we will analyse how such conceptions of health and disease have found expression in the visual representations of the face in the West and the East in an attempt to identify and describe the main effects of the meaning emerging from them.

\section{The face of health in the Western collective imaginary}

Among the first representations of health in the Western collective imaginary special mention should be made of Hygeia (from the Greek 'Yyicı,' 'health'), the Greek divinity of physical and spiritual health, cleanliness and hygiene. Two main phases in the cult of this figure are known: at first as an independent goddess; then in connection with the worship of her father Asclepius, the god of medicine who was invoked for the treatment of disease and the restoration of lost health, while Hygeia was mostly related to the prevention of illness. Correspondingly, in plastic arts the goddess was initially depicted alone, as a virgin of majestic stature with a crowned head; then, towards the third century, she took on the form of a graceful girl accompanied by Asclepius himself and/or by the animal with which he was traditionally depicted: the snake. ${ }^{15}$ In fact, her figure mainly acquired meaning in relation to such elements, thus stressing the difference between prevention and treatment and insisting on a broader conception of health. This did not confer much importance on her face, which mostly responded to the common canon in classical art, without expressive marks of particular relevance.

14 WHO 2020. Basic documents. (49th ed.), available at https://apps.who.int/gb/bd/, was last accessed on 11 December 2020.

15 An extensive literature on the symbolism of the snake exists. With reference to the figure of Asclepius, from which the association with Hygeia seems to have derived, the idea of knowledge is generally highlighted, in addition to the reference to the legend according to which the god of medicine, seeing a snake reviving another with herbs, used them to save Glauco (MurilloGodínez 2010). Furthermore, in Greek mythology, Asclepius exercised his healing powers precisely with the help of a snake, which was able to heal wounds by licking them with its tongue (for further information, see Gutiérrez, Mellado, Saavedra 2004; Rillo 2008, while Hæger 1988 instead insists on the possibility of a reference to the parasite Dracunculus medinensis). 
In Roman times the veneration of health, known in Latin as Salus (or, less frequently Valetudo) grew further, to the extent that the goddess was depicted on numerous coins of the Empire, as its protector. The Roman Salus was in fact the personification of a broader idea of 'well-being', understood as the combination of physical health and prosperity, which concerned both the individual level (as in case of the Greek divinity Hygeia) and the Res publica (i.e. the social sphere). Salus was usually represented seated, with her legs crossed (in the same position generally used for the goddess Securitas, thus further enhancing the link with the social and political dimension) and her elbow lying on the armrest of a throne, ${ }^{16}$ or more commonly in an upright position. ${ }^{17}$ She often held a patera (i.e. a deep plate used in religious ceremonies) in her right hand to feed a snake which was generally wrapped around an altar (or the arm of the throne where Salus was sitting, or the rod that she usually held in her left hand), sometimes directing its gaze towards the plate, sometimes towards the same point where the goddess was looking. While the back of coins generally hosted similar images, the front was used for the representation of the face - of the emperor in power or, in some cases, of Salus herself. The ornaments adorning the head and the face of the goddess played a crucial role in these cases, emphasizing the public dimension of health and the values of wealth and power. The internal elements of the face, on the contrary, were not particularly emphasized, as evidenced by the choice of representing it in profile and the recurrence of ideal and neutral traits, ${ }^{18}$ or at most of symbolical (rather than realistic) portraits of female representatives of the Empire. ${ }^{19}$

Most examples in classical iconography do not differ much from such representations, even when they extend to other cultural systems (as it happens with Sirona in Celtic mythology) and subsequent reinterpretations (such as in Neoclassical statues and paintings). The face of health, in other terms, mainly

16 See, for instance, the back of the denarii of emperors Nerva (Marcus Cocceius Nerva Caesar Augustus, 96 AD), Marcus Aurelius Antoninus Augustus (161-180 AD), Lucius Septimius Severus Augustus (210 AD), and Caracalla (Marcus Aurelius Antoninus Augustus, $212 \mathrm{AD}$ ).

17 See, for instance, the back of the denarii of consul Manius Acilius Glabrio (49 BC), and emperors Caracalla (Marcus Aurelius Antoninus Augustus, 201 AD) and Elagabalus (Caesar Marcus Aurelius Antoninus Augustus, 218-219 AD), as well as the back of the Antoninianii of emperors Philip the Arab (Mark Julius Philip Augustus, 244-245 AD), Marcus Piavonius Victorinus (270-271 AD), Marcus Aurelius Probus (281 AD) and Maximian (Marcus Aurelius Valerius Maximianus Erculius, 290-291 AD).

18 See, for instance, the front of the denarius of the Consul Manius Acilius Glabrio, 49 BC.

19 Such as Livia Drusilla, the third wife of emperor Augustus of Rome, mother of emperor Tiberius, and grandmother of emperor Claudius, on the front of a coin of the Emperor Tiberius Julius Caesar Augustus, 22-23 AD. 
remains a neutral and "perfect" surface to be adorned with symbolical elements, which are the ones conferring meaning on it.

A completely different representation appeared in 1894, when Gustav Klimt was commissioned, together with Franz Matsch, to create large decorative panels for the University of Vienna. Requested to represent philosophy, medicine and jurisprudence, the artist created three large paintings, which caused an uproar among the university establishment and were never displayed to the public, but transferred to the Österreichische Galerie. Later purchased by August Lederer and Koloman Moser, the paintings were relocated to the Immendorf Castle during World War II, where they perished in 1945 due to a fire started by the retreating SS. Focusing on the representation of medicine (Fig. 1, left), it is interesting to notice first of all that, despite the commissioned subject, Hygeia was preferred to Asclepius, insisting on health as a general concept rather than on the process of healing. In fact, the painting is marked by an evident dysphoric characterization. The Greek personification of health stands in front of a vertical tangle of naked bodies composed of pregnant women, children and elderly people, along with skeletons - i.e. allegories of the processes of generation, life, decay and death. Contrary to the iconographic tradition briefly outlined above, in this case Hygeia does not convey any idea of well-being or social welfare: turning her back on humanity, she rather leaves it helpless against a sad fate. The whole group, confined to the narrow space of what can be interpreted as a large uterus - which is connected to another female figure ("mother nature"?), also turning her back on it - is wrapped by a dark veil, in a further negative axiologization.

Looking in detail at the figure of Hygeia (Fig. 1, right), other interesting elements can be identified: in this case the snake is located in front of the patera, without taking anything from it. Although framed from below to highlight its majesty, the face of the goddess is marked by a severe expression and particularly emphasized shadows, which recall the blackish halo characterizing the group of figures in front of which she appears. The dysphoric effect thus generated is further enhanced by Hygeia's gaze, which appears as dejected and absent. What Klimt depicts here is definitely a lost and unattainable health. The goddess of his painting is certainly powerful, but also indifferent to humanity. Therefore, the malaise becomes existential, inevitably leading to illness and death. 

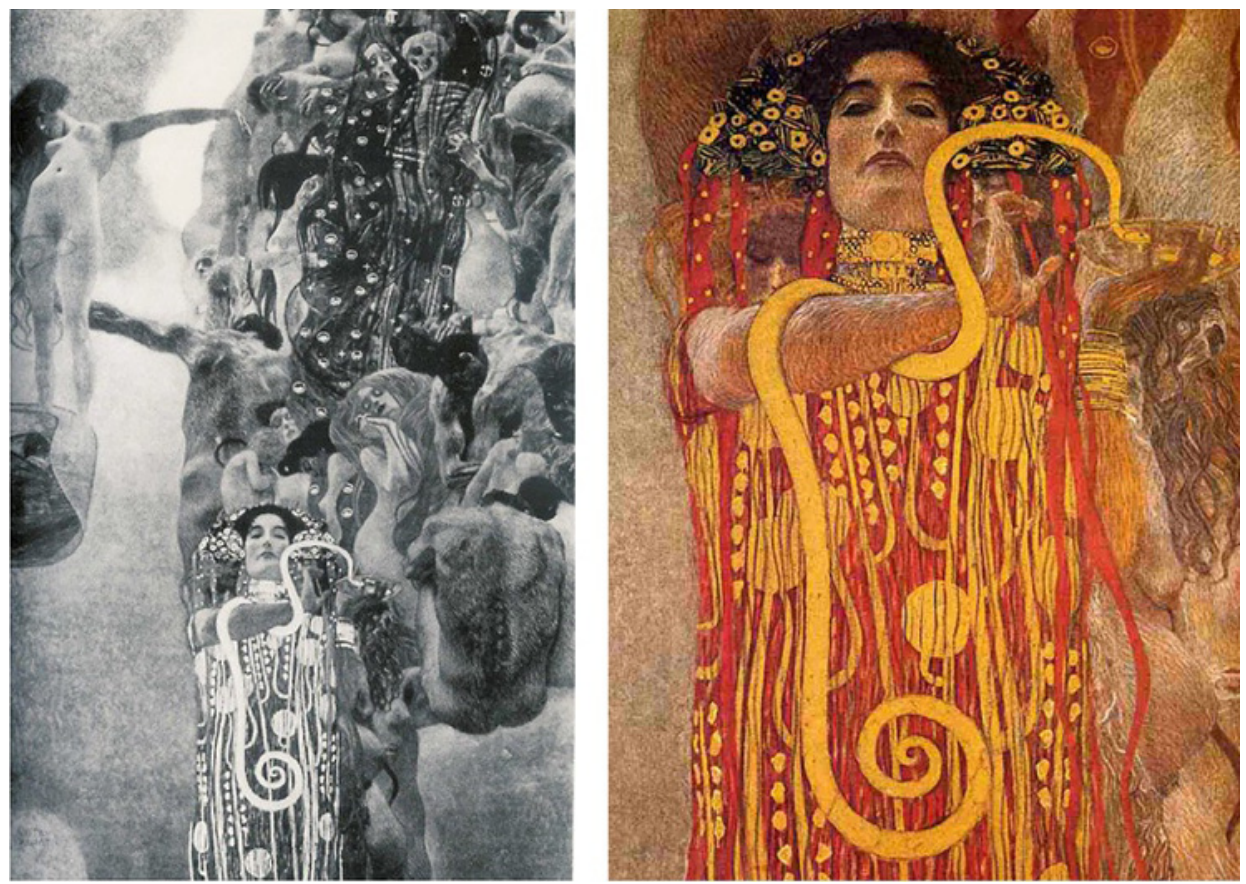

Figure 1. Gustav Klimt. Medizin. (1987, oil on canvas, lost work).

This representation is very interesting, and is in opposition not only to past but also to current discursivizations of health. In fact, in contemporary Western societies the most varied media ranging from wellness and fitness magazines to brochures illustrating anti-aging treatments and weblogs devoted to body care, etc., have contributed to the creation and circulation of countless representations of health, conferring a special role on the face. Despite the peculiarities of each example, such representations seem to respond to the same logic: the "face of health" they depict is always characterized by the (figurative or metaphorical) elimination of a sort of "patina" or "veil" made up of spots, wrinkles and other "signs" marking the facial surface. Differential systems consisting in confronting a 'before' and an 'after', or a 'with' and 'without' condition are largely used, thus emphasizing a differential conception of health, even when the emphasis is put on well-being. This results in a progressive movement of desubjectivation and "perfection" of the face, sometimes also leading to its decomposition in sets of lines, points and intersections (recalling some practices of Eastern medicine, with which we will deal in detail below). The "face of health", in other terms, seems to be irrepresentable as such, at least as a realistic, particularized and "subjectified" face. It is an "unmarked", and therefore 
ideal, surface, which can only be represented in a differential way, that is to say, by making reference to its opposite - i.e. the "face of illness", or at least of malaise (such as in the case of the imperfections brought about by age). The latter, on the contrary, finds expression in a multiplicity of representations, not only in media communications, but also in the medical domain, as we will discuss in the following section.

\section{The face of illness in Western medicine}

Western medicine has historically attributed a fundamental role to the face. As Jean Starobinski (2003: 58) recalled:

A solid tradition required to expose human anatomy a capite ad calcem, that is to say, from head to heel. The method is still followed in some contemporary medical schools, as a rule of preliminary clinical description: the face will therefore be the object of primary attention, whatever part of the body is designated by the patient's complaints. And with good reason: it is on the face that anxiety, suffering and the fundamental gesture of presence to oneself and to the world are inscribed. In a first approximation, it is therefore the face that reveals the state of alertness, numbness, unconsciousness: thus, a first measurement of the severity of the disease becomes possible. ${ }^{20}$

Hippocrates himself, who is considered the father of Western medicine, underlined the importance of observing the face in a famous passage from his Prognosticon: "He [the physician] should observe thus in acute diseases: first, the countenance of the patient, if it be like those of persons in health, and more so, if like itself, for this is the best of all" (Book II, 110 [1849: 235]; my emphasis. S. S.). This finds correspondence in the concept of facies, that is to say, the appearance of the face characteristic of particular pathological conditions (Dorland 2011), which is still fundamental in the processes of medical diagnosis. Echoing the differential dynamics outlined above, medical treatises distinguish between a facies composita (i.e. the unaltered face of healthy people) and a multiplicity of facies marked in various ways, such as the Hippocratic facies (which was called after Hippocrates

20 "Una solida tradizione prescriveva di esporre l'anatomia umana a capite ad calcem, dalla testa ai talloni. Il metodo è ancora seguito in alcune scuole mediche contemporanee, come regola della descrizione clinica preliminare: il volto sarà dunque oggetto di uniattenzione prioritaria, qualunque sia la parte del corpo designata dai lamenti del malato. E a buon diritto: è sul volto che s'inscrivono l'ansia, la sofferenza e il gesto fondamentale della presenza a sé e al mondo. In prima approssimazione è dunque il volto a rivelare lo stato di vigilanza, il torpore, l'incoscienza: diventa cosi possibile una prima misurazione della gravità del male." 
himself, since he first described it, and refers to a face characterized by a sharp nose, sunken eyes and temples, drawn-in ears and distorted lobes, together with hard, stretched and dry facial skin, and pale or dusky colour), the facies virile (typical of hirsutism and characterized by the presence of hair and beard on female faces), the acromegalic facies (marked by low forehead, eyebrow arches and prominent cheekbones, large nostrils, thick lips, pronounced chin, as well as hypertrophy of the tongue and ears), and several others. The underlying logic, in other words, always seems to be the one we identified for media representations: the marked face of disease opposes the unmarked face of health, which seems in fact to be irrepresentable as such, as evidenced by the absence of iconic exemplifications (at least devoid of differential logics such as 'before' $v s$. 'after' comparisons) of the facies composita.

Compared to other approaches, however, Western medicine has highlighted the limits of face reading, at least if not accompanied by other types of analysis. It insists on the fact that the anatomical structures that make up the face are varied and can be altered in different ways, emphasizing the role played by factors such as age, sex, race, individual constitution, degree of consciousness, character, and also cultural influences: "[...] the temptation to believe that all affections are inscribed in the face is great, and, in every age, the presumptuous observer has been able to believe to be in possession of a universal semiology. The presumption consists in believing that the face offers adequate and sufficient clues"21 (Starobinski 2003: 59). Yet judgments of people's health based on their facial appearance remain fundamental in diagnostic and prognostic practices, as well as in everyday life, also resulting in forms of social isolation and stigmatization (Henderson et al. 2016: 1).

\section{The face, health and fortune in the East}

The face plays a crucial role in the Eastern semiosphere. Identified as the most expressive part of the body, the face has received great attention in Eastern and more specifically, Chinese - physiognomy, based on a resemblance between the corporeal dimension and the universe that is understood not simply as metaphorical, but rather as physical (Wang 2020: 175). A section in The Compendium of Divine Physiognomy (Shenxiang quanbian, 神相全編), “The pandect of the face” (Toumian zonglun, 頭面 總論), for instance, highlights that the face

\footnotetext{
21 "La tentazione di credere che tutte le affezioni s'inscrivano nel volto è grande, e, in ogni epoca, l'osservatore presuntuoso ha potuto credersi in possesso di una semiologia universale. La presunzione consiste nel credere che la faccia offra indizi adeguati e sufficienti."
} 
[...] is in the sublime location among the hundred parts of the body, leading to the divine paths of the five viscera, developing the image of the three realms [of the Book of Changes], and determining the gains and losses of the whole body. (Shenxiang quanbian, juan 3, 1-3, quoted in Wang 2020: 155) 22

Furthermore, the face is seen as an index of the five viscera, thus representing a sort of miniature of the inner body. This explains the success of the practice known as 面相, Mian Xiang or Mian Shiang (literally 'face reading'), which is thought to have been developed in China approximately three millennia ago by Taoist healers and monks ${ }^{23}$ and is still in vogue, though with considerable differences (Kohn 1986), among practitioners of so-called Traditional Chinese Medicine and various currents in alternative medicine (which nowadays are also practised in some Western countries).

Despite the peculiarities of the multiple methods of analysing facial structures and describing divisions of the face in Eastern physiognomy, a correspondence between specific organs or parts of the body (such as, for instance, the liver or heart) and particular areas of the face (for example, the eyebrows or the nose) can be identified. In such a perspective, issues related to the former manifest themselves with alterations of the latter (e.g. rashes, skin discolouration, dryness, etc.), in a logic that, echoing the above-described dynamics, views the disease as a marked term and health as an unmarked one.

The aspects considered in Mian Xiang, however, are not limited to the purely physiological dimension, embracing different factors and extending to the realm of divination. A crucial reference, for instance, is the conceptual scheme of $W u$ Xing, or "Five Elements" - i.e. wood (木, mù), fire (火, huŏ), earth (土, tú), metal (金, jin) and water (水, shui), which are linked to each other by positive (creation-transformation) and negative (destruction-control) cycles. The visual representation of such relationships has given rise to a series of "holistic" maps of the face which, in addition to physical health, involve a wide range of factors, such

22 The section is also present in the earlier Mayi manual (Mayi shenxiang, juan 2, 2), as reported in Wang 2020: 155.

23 As reported by Kohn (1986: 255), standard modern physiognomy goes back to the tenth century and, "being established as a standard tradition, was transmitted auspices of Taoism. As is physiognomy itself, Taoism is concerned with the human body and closely related sciences of divination. However, when in the tenth century physiognomy began to stand on its own feet, its interrelatedness Taoist tradition became less obvious, [...]”. In the only work on physiognomy in the Taoist Canon remaining today, the Lingxin jingzhi, the emphasis is placed particularly on the significance of the eyes, ears and the mind which are called the "three lights" of man, and facial symptoms are related to certain periods of time (Kalinowski 1985). 
as personality, temperament, talents, etc., putting them in direct correlation with specific points of the face.

Particular attention has historically also been devoted to the shapes (with ten different facial forms described in the Divine Fortuneteller Ma Yi, cf. Shi, Wu 2016: 72-73), colours [which are considered in details in the Dunhuang (P. 3390), as remarked by Hou (1979), and in the Zhengyifawen xiuzhen yaozhi (DZ 1270; 13b-14a), which has been studied by Strickmann (1985)], and parts of the face [reaching the very articulated systematizations of the Divine Fortuneteller Ma Yi, where eyebrows were classified into 23 types in terms of denseness and sparseness, the inclining angles, continuity; eyes into 33 types in terms of the inclining angles, interocular breadth, eye fold of the upper eyelid, opening height and direction of eyeslits; mouths into 16 types in terms of thickness of lips, breadth of the oral fissure, direction of the oral fissure, closure of the lips; noses into 24 types in terms of shapes of nasal tip, nasal profile, nasal root height, breadth of alae nasi; and so on and do forth (Shi, Wu 2016: 73)], always combining medical aspects with divination (Despeux 2005). The system of the Five Officials (wuguan, 五 官), for instance, identifies the ears as the Officials of Adoption and Audition (caiting guan, 采聽官), the eyebrows as the Officials of Longevity (baoshou guan, 保壽官), the eyes as the Officials of Inspection (jiancha guan, 監察官), the nose as the Official of Judgment and Discernment (shenbian guan, 審辨官), and the mouth as the Official of Income and Expenditure (chuna guan, 出納官), linking them to the representation of good fortune in different phases of a person's life. At the same time, the Five Officials are believed to mirror the viscera and inner organs, revealing internal disease to the outside: the ears reflect the status of the kidneys, the eyebrows the gallbladder and the heart, while the nose, the lungs, and the mouth the overall system of the five viscera, making internal imbalances and problems manifest on the outside.

As remarked by Xing Wang (2020), it is essential to note that, regardless of the specificities of each model, all the different ways of analysing the face in Eastern physiognomy seem to conceive it as

[...] a comprehensive replica of the universe, with different officials, geographic landscapes, and celestial bodies all positioned on the corresponding facial areas. The face is a microcosm within another microcosm (the whole body). [...] Although the body is always transforming through time, larger patterns of its movement are already visible at the beginning of a person's life, spatialised on the face in accordance with the cosmic order. (Wang 2020: 170) 


\section{Physiognomy between the East and the West}

The practice of assessing people's personality and identity by analysing their body and especially their face is not confined to the Eastern semiosphere. In fact, physiognomy originated in classical antiquity, spreading both in the East and in the West. In Western culture, it developed through different works, including the volume De Physiognomonia by Polemo of Laodicea (2nd century AD), Physiognomonica by Adamantius the Sophist (4th century), and the manuscript de Physiognomonia by an anonymous Latin author (approx. 4th century), as well as the reflections of famous Latin authors such as Juvenal, Suetonius and Pliny the Elder. Moving from earlier classical works to Medieval studies, physiognomy particularly developed its predictive and astrological side, digressing into prophetic folklore and magic. It was then reintegrated into the scientific field, experiencing a period of fervent development in the 16th century, especially with Giovan Battista Della Porta, who focused on how people's temperament influences their facial appearance and character, followed by Johann Kaspar Lavater, who introduced the idea that physiognomy relates to the specific character traits of individuals, rather than general types, Franz Joseph Gall, who developed the theory of 'organology' and the method of 'cranioscopy' (later known as 'phrenology'), and Cesare Lombroso, who proposed physiognomy as a means of detecting criminal tendencies. Subsequently it suffered a progressive lull of interest, becoming a "parascientific discipline".

By contrast, in Eastern culture, physiognomy is still widely accepted and practiced, especially in China, where the relation between facial features and "destiny" has never stopped playing a crucial role. Souphiyeh Samizadeh (2020), for instance, has highlighted its importance in the cosmetic procedures offered nowadays by aesthetic practitioners, as well as in the main treatments requested by patients, pointing out the diffused belief in the influence of facial appearance on various aspects of life, such as luck, career, etc. Apart from these aspects, as mentioned above, facial examination has always been a primary component of the diagnostic method in Traditional Chinese Medicine, serving for both preventive and healing practices. Advancement in computer vision and Artificial Intelligence have also lead to Face Reading Technologies-based applications, which are offering new, individual techniques for health check-up and advice to everyone (see Ding et al. 2019). All these practices reiterate what was observed in the previous examples, making the face appear as a sort of blank, unmarked canvas on which illness, moral deviance, and even the caprices of fate leave their traces or marks. 


\section{Conclusion}

Although the examples considered above certainly do not exhaust the wide and extremely varied universe of the discursivization of the face of health, they allow drawing interesting observations from the point of view of the processes of meaning-making. Despite the differences between the Western and the Eastern semiosphere, the face of health always appears as a sort of "zero degree" of the face, functioning as a surface for the inscriptions of malaise and disease (and in some cases even of deviance and negative predispositions). Thus, if on the one hand, such a "zero degree" is euphorically characterized by the absence of disease and, more generally, of divergence, on the other hand, contrary to the Barthesian ideal of a not connoted and not ideologized "face-Idea" (Barthes 1957), it paradoxically ends up being reduced to an anonymous "average face" (van Campen $2000 ;{ }^{24}$ Guido et al. 2017; Roelens 2017). It is an "empty" face, deprived of the signs of nonconformity, but with them also of its own singularity and identity (as it becomes evident in the practice of Mian Xiang), in favour of the adaptation to an unmarked ideal that interprets every redundancy in a way that dominates and eliminates it under the guidance of specialized and "scientificized" knowledge. In fact, it should not be forgotten that any face offering itself to recognition is not a given object, but rather a reality continuously re-constructed by symbolic systems (Magli 1995: 21-25), even though it is treated as a surface through which something internal (e.g. a disease, a moral inclination, or a specific predisposition) can be reflected on the outside, and therefore subjected to presumptive approaches (from medical semiotics to physiognomy and divination).

It is in this sense that the analysed cases recall the two movements of the abstract machine of 'faciality' (visageité) described by Gilles Deleuze and Félix Guattari in Mille Plateaux (1980): on the one hand, a principle that distributes and orders different elements (e.g. points, lines, areas) to constitute a facial unit; on the other hand, a criterion that selects and excludes non-conformities, relegating them to anomaly and deviance (at a physical level, in the case of Western medicine, but also a behavioural one, in the case of Mian Xiang and some practices deriving from Chinese medicine, as well as in the case of physiognomy).

This is highly relevant, since it highlights what we could define the "unattainability" of the face of health. As we pointed out in the previous sections, whether we consider the anonymous, or in any case interchangeable, faces of Hygeia or Salus, which are marked by the symbolism of the ornaments they wear rather

24 Van Campen, Crétien 2000. De aantrekkingskracht van gemiddelde gezichten. Psychologie Magazine, March 2000, available at http://www.synesthesie.nl/pub/gezicht.htm, was last accessed on 9 February 2020. 
than their intrinsic features, or Western medicine's facies composita without any representation, or even the de-personalized and unnatural representations found in magazines and online communication on well-being, we are always dealing with a generic, anonymous, and "a-significant" face, constructed by difference with respect to the multiple faces which, giving expression to deviance, disease or at least forms of malaise, fully fall within the idea of corps propre, or 'MyselfEnvelope', described by Fontanille (2004: 22) "what is constituted in semiosis, what is constructed in the encounter of two levels of language, in the discourse in progress" 25 - and which, therefore, is the bearer of identity and its unceasing processes of re-definition.

In conclusion, the analysed cases show how, in a sort of "veridictory determinism", it is only in the symptomaticity of illness (i.e. the marked facies of Western medicine, the "signs" of Chinese facial reading, etc.), or at most of malaise (i.e. the traces left by ageing), and deviance, that truth (Greimas 1966) seems to be able to manifest itself: by "breaking" the machine of faciality and pluralizing the supposed unitary and perfect state of health that the above-described representations promote, symptoms stand out for their diversity and specificity, revealing (unveiling) to the outside internal processes that were inaccessible before. The asymptomatic face of today's health and well-being, on the contrary, seems to be inevitably destined to fall into a lie (of cosmetic surgery, whether it contrasts physical problems, moral inclinations or negative predispositions, anti-aging measures, photo editing, etc.), or at the most into a secret (of an invisible disease, imperceptible from the outside, which is often all the more dangerous for this very reason). This is a somewhat paradoxical phenomenon, especially if we consider the incredible quantity of images of faces that, from the pages of wellness magazines to the trendiest posts of weblogs and social networks, promise us to "give body" to health, yet in fact all end up contributing to reinforcing of such dynamics. And it is perhaps even more contradictory if we think of a rather common, yet problematic, expression that we generally use to compliment sound people: "You are the picture of health!"

25 "Ce qui se constitue dans la sémiose, ce qui se construit dans la réunion des deux plans du langage, dans le discours en acte." (My translation, S. S.) 


\section{References}

Barthes, Roland 1957. Mythologies. Paris: Seuil.

Barthes, Roland 1972. Sémiologie et médicine. In: Bastide, Roger (ed.), Les sciences de la folie. Paris: Mouton, 37-46. https://doi.org/10.1515/9783111558370-002

Deleuze, Gilles; Guattari, Félix 1980. Mille plateaux. Paris: Éditions de Minuit.

Despeux, Catherine 2005. From prognosis to diagnosis of illness in Tang China: Comparison of the Dunhuang Manuscript P3390 and medical sources. In: Cullen, Christopher; Lo, Vivienne (eds.), Medieval Chinese Medicine: The Dunhuang Medical Manuscripts. London: Routledge, 31-83.

Ding, Xianghua; Jiang, Yanqi; Qin, Xiankang; Chen, Yunan; Zhang, Wenqiang 2019. Reading face, reading health: Exploring face reading technologies for everyday health. Paper No 205. In: Brewster, Stephen; Fitzpatrick, Geraldine; Cox, Anna L.; Kostakos, Vassilis (eds.), CHI '19: Proceedings of the 2019 CHI Conference on Human Factors in Computing Systems. New York: Association for Computing Machinery. https://doi. org/10.1145/3290605.3300435

Dorland, William Alexander Newman (ed.) 2011. Dorland's Medical Dictionary. (32nd ed.) Philadelphia: Saunders/Elsevier.

Fabbri, Paolo 1995. Abbozzi per una finzione della cura. In: Donghi, Pino; Preta, Lorena (eds.), In principio era la cura. Roma-Bari: Laterza, 27-46.

Fontanille, Jacques 2004. Soma et séma. Figures $d u$ corps. Paris: Maisonneuve \& Larose.

Fontanille, Jacques 2005. Il malessere. In: Marrone, Gianfranco (ed.), Il discorso della salute. Verso una sociosemiotica medica. Roma: Meltemi, 35-50.

Fontanille, Jacques 2013. Figures of the body and the semiotics of imprint: Semiotic figures of the body in the humanities. Chinese Semiotic Studies 9(1): 37-52. https://doi. org/10.1515/css-2013-0104

Greimas, Algirdas J. 1966. Sémantique structurale. Paris: Larousse.

Greimas, Algirdas Julien; Courtés, Joseph 1982[1979]. Semiotics and Language: An Analytical Dictionary. (Crist, Larry; Patte, Daniel, trans.) Bloomington: Indiana University Press.

Guido, Laurent; Hennard Dutheil de la Rochère, Martine; Maire, Brigitte; Panese, Francesco; Roelens, Nathalie (eds.), 2017. Visages. Histoires, représentations, créations. Lausanne: BHMS.

Gutiérrez, Lenin Vladímir; Mellado Pérez, Adrián; Saavedra, María de los Ángeles 2004. Origen y evolución del símbolo de la medicina. Educación Médica Superior 18(2): 1.

Hæger, Knut 1988. The Illustrated History of Surgery. New York: Bell Publishing Company. Henderson, Audrey J.; Holzleitner, Iris J.; Talamas, Sean N.; Perrett, David I. 2016. Perception of health from facial cues. Philosophical Transactions of the Royal Society B: Biological Sciences, 371: 20150380. https://doi.org/10.1098/rstb.2015.0380

Hippocrates 1849[C. 400 BCE]. Prognosticon. In: The Genuine Works of Hippocrates. Vol. I. (Adams, Francis, ed., trans.) London: Sydenham Society.

Hou, Ching-lang. 1979. Physiognomie d'après le teint sous la dynastie des Tang. In: Soymié, Michel (ed.), Contributions aux études de Touen-houang. Paris, Genève, 55-70.

Kalinowski Marc 1985. La littérature divinatoire dans le Daozang. (Paper presented at the Quatrième Colloque Pluridisciplinaire Franco-Japonais, Paris, October 1985.) 
Kohn, Livia 1986. A textbook of physiognomy: The tradition of the "Shenxiang quanbian". Asian Folklore Studies 45(2): 227-258. https://doi.org/10.2307/1178619

Leone, Massimo 2018. The semiotics of the face in the digital era. Perspectives. Journal of RFIEA, the French Network of Institutes of Advanced Studies 17: 27-29.

Lotman, Juri M. 1977. Primary and secondary communication-modelling systems. In: Lucid, Daniel P. (ed.), Soviet Semiotics: An Anthology, Baltimore: John Hopkins University Press, 95-98.

Magli, Patrizia 1995. Il volto e l’anima. Fisiognomica e passioni. Milano: Bompiani.

Marrone, Gianfranco (ed.) 2005. Il discorso della salute. Verso una sociosemiotica medica. Roma: Meltemi.

Merleau-Ponty, Maurice 2012[1945]. Phenomenology of Perception. (Landes, Donald A., trans.). London, New York: Routledge.

Murillo-Godínez, Guillermo 2010. El símbolo de la medicina: la vara de esculapio (asclepio) o el caduceo de Hermes (Mercurio). Medicina Interna de México 26(6): 608-615.

Rillo, Arturo G. 2008. El origen griego del caduceo: Esculapio. Colombia Médica 39(4): 384-388. https://doi.org/10.25100/cm.v39i4.620

Roelens, Nathalie 2017. La hantise du visage chez Roland Barthes et Gilles Deleuze. In: Laurent, Guido; Hennard Dutheil de la Rochère, Martine; Maire, Brigitte; Panese, Francesco; Roelens, Nathalie (eds.), Visages. Histoires, représentations, créations. Lausanne: BHMS, 71-88.

Samizadeh, Souphiyeh 2020. Chinese facial physiognomy and modern day aesthetic practice. Journal of Cosmetic Dermatology 19: 161-166. https://doi.org/10.1111/jocd.12980

Sbisà, Marina 2005. Corpo e testo. In: Marrone, Gianfranco (ed.), Il discorso della salute. Verso una sociosemiotica medica. Roma: Meltemi, 69-78.

Sebeok, Thomas 1976. Contributions to the Doctrine of Signs. Lisse: Peter de Ridder Press.

Sebeok, Thomas 2001. Signs: An Introduction to Semiotics. Toronto: University of Toronto Press.

Shi, Bo; Wu, Chao. 2016. Anthropometry in Ancient China - based on the physiognomy book of Divine Fortuneteller Ma Yi. In: Proceedings of the 2nd Annual International Conference on Social Science and Contemporary Humanity Development. Paris: Atlantis Press, 70-75. https://doi.org/10.2991/sschd-16.2016.14

Stano, Simona 2019. La soglia del senso. Il corpo come istanza semiotica. In: Leone, Massimo (ed.), Il programma scientifico della semiotica. Roma: Aracne, 149-162.

Stano, Simona 2020. Between semeiotics and semiotics: The body as a signifying text. In: Soto, Marita; Baeza, Federico (eds.), Alteridades, identidades. Actas $14^{\circ}$ Congreso Mundial de Semiótica: Trayectorias/Proceedings of the 14th World Congress of the International Association for Semiotic Studies: Trajectories. Vol. 2. Buenos Aires: IASS Publications \& Libros de Crítica, 133-140.

Starobinski, Jean 2003. Le ragioni del testo. Milano: Bruno Mondadori.

Strickmann, Michel. 1985. Ensigellation: A Buddho-Taoist technique of exorcism. (Paper presented at the Quatrieme Colloque Pluridisciplinaire Franco-Japonais, Paris, October 1985.)

Wang, Xing 2020. Physiognomy in Ming China: Fortune and the Body. Leiden-Boston: Brill. https://doi.org/10.1163/9789004429550

Yap, Joey 2005. Mian Xiang: Discover Face Reading. Kuala Lumpur: JY Books Sdn Bhd. 


\section{Лицо здоровья на Западе и Востоке: семиокультурный анализ}

Журналы, брошюры, блоги и другие медиа распространяют множество сообщений, в которых советуют, как достичь или сохранить здоровье и благополучие. В подобных сообщениях преобладает иконическое изображение лица и прослеживается интересная закономерность: «лицо здоровья» кажется недостижимым и обычно изображается через его противоположность - «лицо болезни» или, по крайней мере, недомогания. При этом лицо занимает центральное место в медицине: с древних времен наблюдение за лицом играло ключевую роль в диагностических практиках как в западной медицине (которая рассматривает определенный внешний вид или выражение лица как симптом конкретных заболеваний при описании патологических состояний), так и в восточных профилактических и лечебных практиках (важнейшим из которых является так называемое мянь сян, или «чтение лица», связывающее медицинскую сферу с другими аспектами, такими как личность, таланты и наклонности). Опираясь на семиотический анализ соответствующих тематических исследований, начиная от классической иконографии и заканчивая современной цифровой медиасферой, статья исследует репрезентацию лица здоровья (и болезни) во времени и пространстве, уделяя особое внимание аналогиям и различиям между западной и восточной семиосферой.

\section{Tervise nägu idas ja läänes: semiokultuuriline analüüs}

Ajakirjades, flaieritel, blogides ja mitmesugustes muudes meediakanalites levitatakse lakkamatult sõnumeid, mis annavad meile nõu, kuidas saavutada tervist või heaolu või seda säilitada. Sellistes sõnumites domineerib näo ikooniline kujutamine ning tuleb ilmsiks huvitav nähtus: "tervise nägu" kui selline näib olevat saavutamatu ja seda esitatakse üldjuhul eristuse kaudu, osutades selle vastandile, "haiguse näole" või vähemalt halva enesetunde omale. Tegelikult on nägu meditsiinivaldkonnas kriitilise tähtsusega: iidsest ajast peale on näovaatlustel olnud diagnostilises praktikas oluline osa nii lääne meditsiinis (kus patoloogiliste seisundite kirjeldamisel kasutatakse mõistet facies, mille all mõeldakse eristuvat näoilmet või välimust, mis seostub konkreetse meditsiinilise seisundiga) ning idamaistes profülaktilistes ja ravitehnikates (milles on fundamentaalsel kohal niinimetatud Mian Xiang ehk 'näolugemine', mis ühendab meditsiinivaldkonda teiste aspektidega, nagu seda on isiksus, anded ja kalduvused). Artikkel toetub nii klassikalisest ikonograafiast kui ka nüüdisaegsetest digitaalsetest meediamaastikest pärinevate teemakohaste juhtumiuuringute semiootilisele analüüsile ning uurib tervise (ja haiguse) näo kujutamist läbi ruumi ja aja, keskendudes eriti lääne ja ida semiosfääri vahelistele analoogiatele ja erinevustele. Sel eesmärgil toetutakse nii näo kujutamist ja mõistmist käsitlevale kirjandusele kui ka meditsiiniliste märgisüsteemide ja diskursuste uuringutele. 